\title{
OD WARTOŚCI HUMANISTYCZNYCH DO TEOLOGICZNYCH \\ O ODWOŁANIACH DO LITERATURY PIĘKNEJ W HOMILIACH I PRZEMÓWIENIACH JANA PAWŁA II
}

Jan Paweł II jest głosicielem nie tylko Dobrej Nowiny, lecz także ogólnoludzkich, humanistycznych wartości, które są zapisane m.in. w dziełach literackich. Wielokrotnie odnosi się do starożytnej triady Platona i jej humanistycznej aksjologii. Przywołuje myśl Ateńczyka pielgrzymując także do narodów, które rozwijały się poza kulturą grecko-rzymską. Przykładowo, w Azerbejdżanie zwraca się do reprezentantów wspólnot religijnych oraz świata polityki, kultury i sztuki w słowach: „Drodzy przyjaciele, przedstawiciele świata kultury i sztuki, przywracajcie w tych, którzy do was przychodzą, upodobanie do piękna! Jak uczą starożytni - piękno, prawdę i dobro łączy nierozerwalna więź" (DZ XIII 282). Przez wieki wartości te powracają w wypowiedziach filozofów, teologów, myślicieli, pisarzy. Obecne są np. w twórczości Fiodora Dostojewskiego, którego cytuje Jan Paweł II. Znawca dzieł Rosjanina pisze: „Prawda jest bowiem dobrem wypowiedzianym przy pomocy ludzkiego rozumu, a piękno, jako dobro i prawda zarazem, wyraża się poprzez konkretną formę" (Sołowiow 349). Dla Dostojewskiego prawda, piękno, dobro są trzema nierozdzielnymi przejawami tej samej absolutnej idei (Sołowiow 350).

Te trzy wartości humanistyczne są zwrócone w stronę Transcendencji, a Papież, przyjmując platońską ideę ich jedności, dostrzega w niej obecność Boga, co jest też zgodne z bliską mu tradycją Tomasza z Akwinu. Nurty tomistyczne, mając na uwadze aspekt ontologiczny, uznają prawdę, dobro, piękno za właściwości bytu (transcendentalia) i odnoszą je do Boga (Tatarkiewicz 9; Kiełbasa 251-280).

Dr hab. AnastaZja Seul, prof. UZ - Pracownia Teorii Literatury i Badań Kulturowych oraz Pracownia Badań nad Aksjologią w Języku i Kulturze w Instytucie Filologii Polskiej UZ; adres do korespondencji: Uniwersytet Zielonogórski, al. Wojska Polskiego 69, 65-762 Zielona Góra; e-mail: a.seul@wp.pl. ORCID: http://orcid.org/0000-0001-7137-2109. 
Wśród wartości teologicznych w wypowiedziach Papieża można wyodrębnić także swoistą triadę, która wskazuje na cnoty teologalne: wiarę, nadzieję i miłość (Góralczyk 144). Jan Paweł II mówi o nich podczas audiencji ogólnej, wykorzystując siłę ekspresji poetyckiego porównania: „Wiara, nadzieja i miłość są jak trzy gwiazdy jaśniejące na niebie naszego życia duchowego” („Wiara, nadzieja i miłośc”” p. 1). Wskazuje na ich rolę w duchowości chrześcijan w następujący sposób:

Są one w najwyższym stopniu cnotami «teologalnymi»: pozwalają nam żyć w komunii z Bogiem i wiodą nas do Niego. Tworzą tryptyk, którego szczytem jest miłość, agape, wspaniale wysławiana przez św. Pawła... Kończy się on następującym stwierdzeniem: «Tak więc trwają wiara, nadzieja, miłość - te trzy: z nich zaś największa jest miłość». (p. 1)

Teologia duchowości podkreśla ich nierozerwalną więź (Góralczyk 144), o niej też świadczy nauczanie Papieża.

\section{W KRĘGU FILOZOFII}

Na teksty Jana Pawła II warto spojrzeć od strony aksjologicznej, gdyż ta perspektywa zawsze jest obecna w wypowiedziach wykładowcy etyki, znawcy pism Maxa Schelera i autora prac filozoficznych.

\section{PRAWDA}

Prawda w rozumieniu Jana Pawła II ma wartość nie tylko filozoficzną (adaequatio rei et intellectus) $)^{1}$, ale też wartość teologiczną (por. J 14,6; Słomka, „Prawda” 700-701). Przemawiając w Olsztynie 6 czerwca 1991, podejmuje Papież temat VIII przykazania, nawiązuje do poematu „czwartego wieszcza” - jak nazywa Norwida:

Przypatrzmy się znaczeniu prawdy w naszym życiu publicznym. W odnowionej Polsce nie ma już urzędu cenzury, różne stanowiska i poglądy mogą być przedstawiane publicznie. Została przywrócona - jakby powiedział Cyprian Norwid - «wolność mowy» (Rzecz o wolności stowa). Wolność publicznego wyrażenia swoich poglądów jest wielkim dobrem społecznym, ale nie zapewnia ona wolności słowa. (PDO 667)

Utwór przywołany przez Jana Pawła II ma formę zbliżoną do poematu dydaktycznego (Chlebowski 58,60) i służy także celom wychowawczym. Podobny cel przyświeca Papieżowi, gdy - jak poeta - zachęca słuchaczy do podążania za tokiem jego my-

\footnotetext{
${ }^{1}$ Zob. szerzej: Maryniarczyk. „Prawda”.
} 
śli, co z kolei ma doprowadzić do metanoi - rozumianej nie tylko jako przemiana myślenia, ale także jako zmiana postaw i zachowań.

W dalszej części cytowanej wypowiedzi z Olsztyna znajduje się kryptocytat z tegoż poematu, w którym Norwid - już we wstępie utworu - dokonuje istotnej dystynkcji między wolnością słowa a wolnością mówienia ${ }^{2}$. Na tę różnicę także zwraca uwagę Papież: „Niewiele daje wolność mówienia, jeśli słowo wypowiadane nie jest wolne" (PDO 667). Odwołanie do myśli polskiego romantyka służy Papieżowi do przeprowadzenia dalszego wywodu: stosując enumerację, bezpośrednio wskazuje na te rzeczywistości, które odbierają wolność wypowiadanemu słowu. Jan Paweł II zauważa, że może być ono „spętane egocentryzmem, kłamstwem, podstępem, może nawet nienawiścią lub pogardą dla innych" (PDO 667). Wymienione antywartości łączy wymiar duchowy, który odsłania prawdę o misterium iniquitatis ludzkiej natury zranionej przez grzech pierworodny. Wyjaśniając, ku komu skierowana jest pogarda, Papież wymienia tych, „którzy różnią się narodowością, religią albo poglądami” (PDO 667), a następnie wyciąga wniosek natury moralnej: „Niewielki będzie pożytek z mówienia i pisania, jeśli słowo będzie używane nie po to, aby szukać prawdy, wyrażać prawdę i dzielić się nią, ale tylko po to, by zwyciężać w dyskusji i obronić swoje - może właśnie błędne - stanowisko" (PDO 667).

Wszelkie zafałszowania w odniesieniu do prawdy prowadzą do tego, że ludzka przewrotność i demoniczna pycha używają prawdy jako „towaru”. Epitet „demoniczna" w odniesieniu do pychy jest uzasadniony tym, że teologia łączy kłamstwo z demonem i pychą; zaś prawdę - z Bogiem i z pokorą (por. J 8,44; Słomka, „Prawda” 700-701; Urbański 647-648). Jan Paweł II, mając na uwadze instrumentalne traktowanie prawdy, dochodzi do pouczającej konstatacji: „Słowa mogą czasem wyrażać prawdę w sposób dla niej samej poniżający. Może się zdarzyć, że człowiek mówi jakąś prawdę po to, żeby uzasadnić swoje kłamstwo [...]. Prawda zostaje poniżona także wówczas, gdy nie ma w niej miłości do niej samej i do człowieka" (PDO 668). W stwierdzeniu tym widoczne jest połączenie prawdy i dobra, jakim jest godność osoby ludzkiej oraz miłość bliźniego.

${ }^{2}$ „Panie i panowie! Dotąd wolność słowa jest tylko zdobywaniem wolności objawiania słowa.

Jest przeto atrybutem wolności osobistej.

Ale o samejże wolności słowa nikt nie mówił. [...]

To, co nazywają wolnością słowa, jest dotąd wolnością mówienia, la liberté de dire...

Zmieszanie tych dwóch pojęć pochodzi z małej znajomości słowa”. Norwid. „Rzecz o wolności słowa”, cz. I. Wersja elektroniczna. 


\section{DOBRO}

Dobro to druga kategoria, o której mówi Jan Paweł II także wówczas, gdy przywołuje literaturę piękną. Bogata jest semantyka tego słowa, a Papież wydobywa różne jej aspekty, nawiązując do kilku dzieł literackich. O dobru, jakie wprost wynika z przestrzegania prawa moralnego, mówi podczas spotkania ekumenicznego w Reykjaviku, gdzie zauważa, że ,życie rodzinne już uległo głębokim przemianom, nie zawsze na lepsze" (DZ XI 554-555) i w kontekście wartości pielęgnowanych na wyspie przypomina Opowiadania islandzkiego autora: „Tradycyjny islandzki dom rodzinny był zawsze szkołą wiary, miłości i zasad moralnych. Jego ducha oddaje opowiadanie napisane przez niedawno zmarłego kochanego w Islandii ojca Jona Svenssona z zakonu jezuitów, poufale zwanego «Ojcem Nonni»" (DZ XI 555). Takie wartości, jakie były wpajane młodym ludziom w domu rodzinnym, jak wiara, miłość, zasady moralne ukształtowały życie Jona Svenssona i przyczyniły się do tego, że w pierwszej połowie XX wieku stał się poczytnym autorem, znanym w świecie ze swych opowiadań bogatych w odwołania autobiograficzne. On to, jako młody człowiek, wyjechał w 1870 roku na naukę do Kopenhagi; wyjazd i naukę umożliwił mu francuski misjonarz; przebywając na kontynencie ukończył kolegium jezuickie i studia teologiczne. Zdobył międzynarodowe uznanie jako autor 12 autobiograficznych powieści dla młodzieży, których bohaterem jest on sam jako Nonni - co jest formą zdrobniałą jego imienia Jon. Prowadził też działalność odczytową aż do 1938 roku, podróżując po Europie, USA i Japonii. Jego opowieści przygodowe były znane także w Polsce dwudziestolecia międzywojennego; realizowały one cele dydaktyczno-religijne (Nawrocki 54-55) . $^{3}$

Cele Jana Pawła II były podobne i służyło im nawiązanie do elementu rodzinnej biografii ojca Nonni oraz konfrontacja z życiem współczesnych rodzin: „Matka pożegnała go prostymi słowami zaczerpniętymi z samego serca waszej tradycji «Bądź uczciwy i nie zapominaj o Bogu». Dzisiaj jednak rodziny stoją w obliczu nowych i groźnych nacisków, którym można stawić czoło jedynie przez odnowiony i pogłębiony szacunek dla życia i miłości” (DZ XI 555). Papież zwraca uwagę na zagrożenie harmonii życia rodzinnego, które wynika z niewierności słowom przysięgi małżeńskiej. Małżonkowie bowiem zobowiązują się do tego, by nie tylko sobie okazywać miłość wzajemną, ale i by z miłością przyjąć nowe, nienarodzone jeszcze życie (Obrzędy sakramentu malżeństwa dostosowane do diecezji polskich 29).

\footnotetext{
${ }^{3}$ Jego opowiadania były również wydawane w Polsce zaraz po wojnie, zanim życie kulturalne w Polsce nie zostało poddane zupełnemu dyktatowi reżimu Związku Radzieckiego; w wydawnictwie jezuitów ukazało się kilka tytułów: Czólnem przez morze (Kraków 1924; 1948), Nonni i Manni dwaj islandzcy chłopcy (1921; 1948), Z dalekiej pótnocnej wyspy (Kraków 1924; 1947).
} 
Jan Paweł II, mówiąc na spotkaniu ekumenicznym o konieczności troski o pogłębiony szacunek dla życia i miłości, wskazuje, że bez tych wartości moralnych niemożliwe jest funkcjonowanie ani rodzin, ani całych społeczeństw (DZ XI 555).

\section{PIĘKNO}

Mając na uwadze trzeci element triady Platona, Papież kilkakrotnie cytuje dzieła literackie, które wprost mówią o pięknie. Wspominany już Dostojewski pojawił się w jego wypowiedzi podczas pielgrzymki do Salzburga:

Co roku przybywa do tego miasta wielu ludzi z całego świata. Panująca tu harmonia architektoniczna i muzyczna pozwala niektórym zapomnieć na chwilę o ogromnych dysonansach dzisiejszego świata. Inni uzyskują dzięki tej harmonii siłę moralną, która pozwala im bardziej niż dotąd angażować się w przezwyciężanie zła. Niejeden gość Salzburga przypomni sobie przy tym słowa Dostojewskiego «Piękno ocali świat». (DZ XI 261)

Słowa te zaczerpnięte są z powieści Idiota ${ }^{4}$ i - jak dowiadujemy się z relacji Hipolita - wypowiedział je książę Lew Nikołajewicz Myszkin. Z całego kontekstu wynika również, iż Hipolit, ten nieuleczalnie chory młodzieniec dystansuje się od przekonań Myszkina, łączącego swe rozumienie piękna z chrześcijaństwem. Postawa księcia Myszkina, którego można uznać za uosobienie ewangelicznego spojrzenia na świat, jest zdecydowanie odmienna od postawy Hipolita symbolizującego brak sensu cierpienia, gdy przeżywa się je bez Chrystusa (Szutta 35-36). O chrześcijańskim nurcie myśli Dostojewskiego pisze prawosławny duchowny, przekonując, iż jest on pisarzem eschatologicznej nadziei zakorzenionej w Ewangelii ${ }^{5}$. Jest to nadzieja, która niesie ocalenie światu. Jan Paweł II, cytując myśl autora Idioty, proponuje jej rozwinięcie: „należałoby zapewne rozszerzyć to zdanie i powiedzieć: «dobro, dobroć, miłość, ocali świat». Chrześcijanin rozumie przez to miłość Bożą, która w Jezusie Chrystusie objawiła się w swej pełnej zbawczej postaci i wzywa do naśladowania Go" (DZ XI 261). Taką wymowę pogłębia dalsze stwierdzenie Ojca Świętego: „Piękno jest tu rozumiane jako odbicie piękności, wspaniałości Boga" (DZ XI 261). W tym

${ }^{4}$ „Ach, prawda - [Hipolit] przeskoczył znowu na inny temat - gdzie jest mówca, gdzież jest Lebiediew? Więc już skończył? O czym on mówił? Prawda, książę, że powiedział pan kiedyś, iż «piękno» zbawi świat? Panowie - zwrócił się głośno do wszystkich - książę twierdzi, że piękno zbawi świat! ... Jakież to piękno ma zbawić świat? Opowiadał mi to Kola... Pan jest gorliwym chrześcijaninem? Kola mówi, że pan sam siebie nazywa chrześcijaninem. Książę przyglądał mu się uważnie, ale nic nie odrzekł" (Dostojewski 402-403).

${ }^{5}$ „Dostojewski jest pisarzem nadziei, nie jest pisarzem rozpaczy. Jednak chodzi w tym wypadku o cnotę nadziei i o nadzieję eschatologiczną. Nie może być zresztą inaczej w wypadku pisarza, dla którego przesłanie Ewangelii było wartością największą” (Paprocki, „Dostojewski pisarzem rozpaczy czy pisarzem nadziei?"). 
komentarzu do słów „piękno ocali świat” widoczna jest aluzja do znanego fragmentu duchowej autobiografii Augustyna ${ }^{6}$. Można zgodzić się z tym, że Piękno, o którym pisze i Dostojewski i biskup Hippony, jest jednym z imion Boga, które znajduje swe odzwierciedlenie w pięknie całego stworzenia ${ }^{7}$.

Podsumowując fragment wskazujący na wartości humanistyczne obecne w papieskich odwołaniach do literatury pięknej, warto zauważyć, że ich punktem wyjścia jest filozofia, a punktem dojścia - teologia ${ }^{8}$. Dlatego w tym miejscu przywołam cytat lubelskiego teologa, który - jak sądzę - można potraktować jako konkluzję:

Argumentacja o harmonijnej strukturze tryptyku [dobro, prawda, piękno - AS], wykazując obecność w objawieniu Chrystusowym najwyższej prawdy (argument werytatywny), dobra (argument bonatywny) i piękna, (argument kaloniczny), nie tylko czyni zadość klasycznemu modelowi doskonałości, lecz także potwierdza słuszność zawartej w nim intuicji, spełnionej ostatecznie w chrześcijaństwie". (Kaucha 136)

W takim ujęciu swą aktualność ujawnia dawna maksyma przedstawicieli scholastyki: philosophia ancilla theologiae est.

\section{W KRĘGU TEOLOGII}

Całe nauczanie Jana Pawła II, choć można je rozpatrywać w perspektywie filozoficznej, jest jednak głoszeniem prawd teologicznych, a Papież postrzega ich komplementarność. Ponadto w papieskich odwołaniach do literatury pięknej obecne są wspomniane już fundamentalne kategorie teologiczne: wiara, nadzieja i miłość.

\section{WIARA}

Wiara w ujęciu teologicznym stanowi fundament życia moralnego, a także jest obowiązkiem człowieka wobec Boga, który mu się objawia (KKK 2087. Por. też Rz 1,5.18-32). Wiara jest darem Boga i - jak każdy dar - jest także zadaniem. Bóg

${ }^{6}$ „«Późno Cię umiłowałem, Piękności tak dawna, a tak nowa, późno Cię umiłowałem, wgłębi duszy byłaś, a ja się błąkałem po bezdrożach i tam Cię szukałem, biegnąć bezładnie ku rzeczom pięknym, które stworzyłaś. Ze mną byłaś, a ja nie byłem z Tobą»” (Augustyn 246).

${ }^{7}$ Myśl ta obecna jest u polskiego przedstawiciela romantyzmu: „«Cóż wiesz o pięknem?»... Ksztattem jest Miłości»”. Promethidion. Rzecz o dwóch dialogach z epilogiem [fragm. Bogumit w. 109]. C. Norwid, Promethidion 76. Por. Sawicki 15. Szerzej papieskie odczytanie myśli Norwida o pięknie zob. Seul, Literatura polska w wypowiedziach Jana Pawta II 169-177.

${ }^{8} \mathrm{O}$ anabatycznym i katabatycznym aspekcie tych wartości zob. Seul, „Prawda. Dobro. Piękno” $97-122$. 
obdarzając człowieka (i całe narody) łaską wiary, zachęca do osobistego zaangażowania w jej rozwój. Wiara pomaga człowiekowi uporządkować życie ziemskie w wymiarze zarówno indywidualnym, jak i społecznym; umacnia poczucie odpowiedzialności za wszelkie decyzje, gdyż człowiek wierzący liczy się z wiecznymi konsekwencjami swych czynów (Słomka, „Wiara” 913-914). Życie na ziemi jest cennym darem Boga, pierwszym jego etapem, który decyduje o dalszym kształcie życia poza granicami śmierci.

O takim postrzeganiu doczesności i wieczności mówi Papież, przybywając do stolicy Liechtensteinu9. Tam też wskazuje na ponad doczesną wartość ziemskiej ojczyzny, cytując słowa hymnu Księstwa: ,jest to bowiem z woli Bożej droga do wiecznej ojczyzny. Dbajcie więc w duchu Chrystusa i Kościoła również o wasz kraj, pamiętając, że: «Ten miły kraj rodzinny, / Ojczyznę drogą/ Mądra Boga ręka/ Dla was wybrała»" (DZ XI 372). Autorem pieśni jest duchowny protestancki ${ }^{10}$, który zgodnie ze swymi chrześcijańskimi przekonaniami potraktował ojczysty skrawek ziemi jako dar Boży. Przywołane przez Papieża słowa hymnu narodowego pozwalają spojrzeć w teologicznej perspektywie także na wartości patriotyczne, zgodnie z nauczaniem Soboru Watykański II o teologii rzeczywistości ziemskich ${ }^{11}$. Spojrzenie w wierze na życie doczesne, na miejsce geograficzne i kulturowe, w którym toczy się ludzka codzienność, ma wielkie znaczenie dla kultury chrześcijańskiej.

\section{NADZIEJA}

Cnota nadziei - jak podaje Katechizm Kościoła Katolickiego - ,jest ufnym oczekiwaniem błogosławieństwa Bożego i uszczęśliwiającego oglądania Boga" (KKK 2090). Chociaż pozostaje skierowana ku życiu wiecznemu, to także jest uwarunkowana spełnieniem wielu nadziei czasowych (Słomka, „Nadzieja” 561).

\footnotetext{
9 „Na tym doczesnym świecie, w drodze do wiecznej ojczyzny ponosimy wielką odpowiedzialność za siebie nawzajem, za nasze własne zbawienie, i za zbawienie innych. Chociaż nie mamy tutaj trwałego mieszkania i wszystko, co z tego świata jest przemijające, naszą odpowiedzialność za ten świat traktujemy bardzo poważnie” (Jan Paweł II, „Przemówienie pożegnalne na lądowisku” p. 2 (8 IX 1985). DZ XI 372).

${ }^{10}$ Hymnem Liechtensteinu został wiersz Jacoba Josefa Jaucha, znany jako „Vaterlandslied” („Pieśń ojczyźniana"). Zob. szerzej na ten temat: Stopyra 47-50.

${ }^{11}$ „Szczególnie ważną dziedziną owej słusznej autonomii jest domena badań naukowych. Nieprzestrzeganie tej zasady doprowadziło w przeszłości do poważnych konfliktów na linii spotkania nauki z wiarą. Istnieje jednak możliwość nieprawidłowego zrozumienia postulatu autonomii rzeczywistości ziemskich, tak jakby rzeczy stworzone nie zależały od Boga i mogły być używane w oderwaniu od Jego praw", teologia-duchowosci.blogspot.com/2008/12/ks-andrzej-siemieniewski-rzeczywistoci. html. Dostęp 29.03.2020.
} 
Temat nadziei często pojawia się $\mathrm{w}$ wypowiedziach Papieża podczas jego pielgrzymek po świecie, lecz rzadko towarzyszą mu odwołania do literatury pięknej. Jednym z nielicznych jest homilia wygłoszona w Brukseli podczas mszy św. dla artystów. Papież zauważa, że: „Nierzadko cień smutku pada dziś na naszą kulturę. Serce ludzkie zdaje się niekiedy niezdolne do nadziei” (DZ X 880), a później mówi o gasnącej nadziei we współczesnym świecie, łącząc to zjawisko z zanikiem wiary w Boga, ze zwątpieniem w Jego miłość i sens ludzkiego życia. Zwraca też uwagę na rolę ideologii materialistycznych, które sprowadzają człowieka do roli przedmiotu, deprecjonując godność osoby ludzkiej. Używając języka aluzji i metafor, stwierdza: „«Podejrzenia» proponowane przez pewne kierunki współczesnej myśli podcinają skrzydła nadziei” (DZ X 881). Słowo ujęte w cudzysłów nawiązuje do określenia Paula Ricoeura, który nazwał Zygmunta Freuda, Fryderyka Nietzschego i Karola Marksa „mistrzami podejrzeń” (Gąsiorowski 85-98). W kontekście tych współczesnych kierunków myślowych Jan Paweł II wskazuje nadzieję, jako na pewnego rodzaju antidotum na kulturę śmierci coraz wyraźniej niszczącą współczesną Europę i świat.

Papież, dbając o dobry kontakt z artystami, do których przemawia, przywołuje Charles'a Péguy'ego, a z jego poematu wydobywa przesłanie nadziei: „Jeszcze inna cnota zakorzeniona w wierze i miłości ożywia chrześcijanina: to nadzieja. Poeta Péguy zachwycał się «małą dziewczynką» - nadzieją" (DZ X 881). Metafora ewokacyjna „mała dziewczynka” wskazuje na nadzieję przedstawioną w utworze Le Porche du mystère de la deuxième vertu ${ }^{12}$. Autor, stosując personifikację, ukazuje w poemacie nadzieję jako małą ufną dziewczynkę (można też przetłumaczyć - „córeczkę”), której towarzyszą dwie starsze siostry: wiara i miłość. Nadzieja jest najbliższą Bogu cnotą:

W wierze najbardziej miłuję nadzieję, mówi Bóg

$[\ldots]$

Ale to nadzieja, ona mnie zdumiewa, mówi Bóg

Mnie samego zadziwia.

(Péguy 31.35$)^{13}$

${ }^{12}$ Wyraz le porche thumaczony na j. polski jako przedsionek albo portyk. Zob. Péguy, Przedsionek tajemnicy drugiej cnoty 31; zob. też propozycja tłum. Portyk misterium drugiej cnoty podana w: Pereira, „Szema Karola Peguy. Człowiek pogranicza” 8. Na temat twórczości Péguy’ego zob. też tej samej autorki: bazhum.muzhp.pl/media//files/Collectanea_Theologica/Collectanea_Theologica-r1999-t69-n2/Collectanea_Theologica-r1999-t69-n2-s71-88/Collectanea_Theologica-r1999-t69-n2-s71-88. pdf. Dostęp 15.04.2020.

${ }^{13}$ Tłumacz informuje, iż w swoim przekładzie zachował francuską interpunkcję. 
Ona nadaje kierunek wierze i miłości, gdyż jej „starsze siostry” podążają za tą „małą dziewczynką", która jest wychylona ufnie ku przyszłości:

To ta malutka wprawia wszystko w ruch.

Wiara widzi tylko to co jest

A ona widzi to co będzie

$[\ldots]$

Nadzieja widzi to czego jeszcze nie ma i to co nadchodzi

Lubi to co jeszcze się nie stało a co przyjdzie.

(Péguy 31-42)

Jeden z komentatorów poematu pisze: „Peguy stosuje tu poruszającą metaforę i poetycki obraz, aby ukazać siłę nadziei, dowodząc jednocześnie jak zaskakującą może być nadzieja, gdy przeżywamy upokorzenie, deprawację, gdy cierpimy, gdy doświadczamy zła w świecie" (Kheriaty i Cihak 313). Nadzieja chrześcijańska, o której pisze poeta, kieruje myśli i uczucia człowieka ku wiecznej przyszłości, pozwalając mu zachować pewien dystans do rzeczywistości doczesnej i tak przetrwać wszelkie trudy.

\section{MIŁOŚĆ}

Miłość jest życiodajną, potrójną relacją: Bóg pierwszy wychodzi do człowieka z darem miłości; człowiek przyjmuje ten dar, a następnie odpowiada na niego taką miłością, do jakiej jest zdolny, kierując ją ku Stwórcy i bliźnim (Słomka, „Miłość” 524-526). W nauczaniu Papieża można odnaleźć te trzy oblicza miłości: dawanej przez Boga, przyjmowanej przez człowieka oraz miłości, którą człowiek daje innym.

Na bezwarunkową miłość, z którą Bóg wychodzi ku człowiekowi, wskazują słowa Jana Pawła II wypowiedziane w Bombaju podczas mszy dla rodzin. Papież, doceniając wkład Mahatmy Gandhiego ${ }^{14}$ w życie hinduskich rodzin, przypomina, iż płodność małżonków jest szczególnym darem Bożej Miłości i wezwaniem do odpowiedzi na tę miłość poprzez troskę o dziecko. W tym kontekście przywołuje aforyzm myśliciela cenionego w Indii i w świecie ${ }^{15}$. „Wedle słów Rabindranatha Tagore, [rodzice] odkrywają tę oto prawdę: «Każde dziecko, które się rodzi/ Przynosi ze sobą wieść, / Że Bóg nie stracił jeszcze wiary w rodzaj ludzki»” (DZ XIII 64).

${ }^{14}$ Gandhi na pytanie, jak ograniczyć prokreację, odpowiada: „nie poprzez zabiegi niemoralne i sztuczne [...] ale poprzez dyscyplinę życia i samokontrolę”. Jan Paweł II, „Trzeba by głos Indii sprzymierzył się z głosem Kościoła” p. 6 (9 II 1986). DZ XIII 64.

${ }^{15}$ Otrzymał doktoraty honoris causa kilku uczelni (m.in. uniwersytetu w Kalkucie), a także był pierwszym Azjatą laureatem Nagrody Nobla (w 1913 roku za angielską wersję jego bengalskiego utworu Gitanjali. Pieśni ofiarne); zob. Tuczyńska 121; Sosnowski 10. 110. 114. 120-121. 
Aforyzm ten inaczej brzmi w polskim thumaczeniu z okresu XX-lecia międzywojennego, które to tłumaczenie mogło być znane Karolowi Wojtyle: „Narodziny każdego dziecięcia zwiastują, że Bóg nie sprzykrzył sobie jeszcze człowieka” (Tagore 17). Zdaniem Tagore, cel istnienia życia nie mieści się tylko w wymiarach biologicznych czy społecznych, lecz realizuje się w odniesieniu do sacrum, dlatego też stworzył w Indiach taki system szkolnictwa, który ukierunkowany jest na prymat wartości duchowych (Krawczyk 98-99). Jeden ze znawców twórczości myśliciela zauważa, że w wielu sentencjach odsłania on swój obraz Boga jako miłości. Stosując apostrofy, Boga nazywa Najukochańszym, Mistrzem, Przyjacielem. Spotkanie z Bogiem budzi radość serca i zaufanie, jakie można mieć tylko do kogoś, kto żyje prawdą i jest najbardziej życzliwym Przyjacielem (Sosnowski 116-119). Bóg jest nieskończenie cierpliwy, hojny i choć jest twórcą nieskończoności, to upodobał sobie człowieka, któremu daje największe prezenty (Sosnowski 183-184).

O człowieku, który przyjmuje otwartym sercem miłość ojcowskiego serca Boga, mówi Papież, cytując znane słowa biskupa Hippony w Brazylii podczas homilii na Mszy św. inaugurującej Kongres Eucharystyczny:

\begin{abstract}
Nasze serce szuka szczęścia, chce go zakosztować w prawdziwej miłość. Tak, chrześcijanin wie, że prawdziwe zaspokojenie tego dążenia odnaleźć można tylko w Bogu, na obraz którego stworzony został człowiek (por. Rdz 1,27). «Stworzyłeś nas Panie dla siebie i niespokojne jest serce nasze, póki nie spocznie w Tobie» (św. Augustyn, Wyznania, I,1). Gdy Augustyn, który przeszedł przez dręczącą i bezowocną pogoń za szczęściem, próbując każdej przyjemności i próżności, pisał te słynne słowa na pierwszej karcie swoich Wyznań, dawał właśnie wyraz podstawowej potrzebie, wypływającej z samej głębi naszego jestestwa. (DZ XII 447)
\end{abstract}

Potrzeba miłości jest wpisana w ludzką naturę wraz z dążeniem do szczęścia. Bóg, który jest źródłem miłości, jest też źródłem szczęścia, dlatego tylko w Nim człowiek może znaleźć pokój serca, a więc swoje szczęście (Czuj XV). Święci wszystkich narodów i pokoleń są ludźmi, którzy zwracają się ku Bogu, przyjmują Jego miłość i dzielą się nią z innymi. Jan Paweł II wielokrotnie w swoim nauczaniu wskazywał na różnych świętych. Jednym z nich był św. Franciszek z Asyżu, z którego inspiracji zrodziła się z początkiem XX wieku poetycka modlitwa znana jako Modlitwa o pokój lub też Modlitwa franciszkańska (Szczerba 108) ${ }^{16}$. Ojciec Święty, przywołując jej słowa na spotkaniu z przedstawicielami organizacji międzynarodowych, wskazuje drogi miłości. Doceniając ich zaangażowanie w budowanie wspólnego dobra, powołuje się na ponadczasowy charakter myśli ubogiego zakonodawcy:

${ }^{16}$ Zob. też Moskwa 390; Modlitwy o pokój 24. Więcej o modlitwie i duchowości franciszkańskiej, o jej źródłach, aktualności i modlitwie pisze o. C. Niezgoda, Śladami Franciszka. 
W jego duchu pozwalam sobie mówić o waszym wkładzie w świat, o tym, co potraficie zrobić dla ludzkości, pracując razem jako bracia i siostry, ponad którymi jest powszechne ojcostwo Boga: Panie, uczyń z nas narzędzia Twojego pokoju! Abyśmy siali miłość tam, gdzie panuje nienawiść; wybaczenie - gdzie panuje krzywda; wiarę - gdzie panuje zwątpienie; nadzieję - gdzie panuje rozpacz; światło - gdzie panuje mrok; radość - gdzie panuje smutek. Abyśmy siali życie tam, gdzie panuje śmierć; byśmy czynili pokój tam, gdzie panuje wojna! Panie, uczyń nas prawdziwymi sługami ludzkości, sługami życia, sługami pokoju! (DZ XI 217)

Przywołany tu obszerny fragment Modlitwy franciszkańskiej ${ }^{17}$ ma charakter kryptocytatu. Został on ujęty w klamrę kompozycyjną, która - umieszczona w tym kontekście - podkreśla znaczenie miłości dla budowania pokoju między narodami ${ }^{18}$. Miłość, o której mówi św. Franciszek, a za nim Jan Paweł II, łączy się z nadzieją i wiarą. Ona też przejawia się w międzyludzkiej życzliwości, która jest ukierunkowana na wspólne dobro.

$*$

Jan Paweł II, przemawiając do artystów w stolicy Unii Europejskiej podkreśla rolę sztuki - także sztuki słowa - w służbie człowiekowi. Tu także, jak w wielu innych jego wypowiedziach, widoczne jest także nauczanie o prymacie wartości duchowych materialnymi:

Jak wiecie, drodzy przyjaciele, sztuka ma szczególne prawo dawać wyraz wierze, miłości i nadziei. Prawdziwa sztuka przyczynia się do obudzenia uśpionej wiary. Otwiera serce na tajemnicę innych ludzi. Podnosi na duchu tych, którzy przeżyli zbyt głębokie rozczarowania albo są zbyt zmęczeni, by żywić jeszcze nadzieję. Chrześcijański artysta ma zatem szczególne zadanie. Przywołuje rzeczywistość ukrytą «pod postacią rzeczy», by powiedzieć «Bóg jest niedaleko od każdego z nas». (DZ X 881-882)

Ta ukryta rzeczywistość, to Bóg bliski człowiekowi, którego tajemnicę ogłasza poganom św. Paweł, przemawiając na areopagu w Atenach (por. Dz 17,22-27).

Papież-pielgrzym miłośnik i znawca literatury pięknej wielokrotnie przywołuje epikę i lirykę, traktując je jako przestrzeń spotkania z ludźmi, do których przybywa z duszpasterską posługą, gdyż widzi w literaturze swoiste locus theologicus. Wskazuje też na takie wartości humanistyczne, jakimi są prawda, dobro i piękno, odsłaniając ich wymiar transcendentny. Zaznacza w ten sposób, że filozofia grecka

${ }^{17}$ Zob. www.panewniki.pl/duchowosc,modlitwy_franciszkanskie,48.html. Dostęp 22.04.2020.

${ }^{18}$ Warto dodać, że Modlitwa franciszkańska nawiązuje swą treścią oraz literacką formą i do tekstu św. Franciszka pt. Cnoty, które usuwają wady. Zob. Św. Franciszek, św. Klara, Pisma 88. Zob. szerzej: Seul, „Odwołania Jana Pawła II do literatury pięknej” 109-130. 
stanowi praeparatio Evangelica, a wiara, nadzieja i miłość mogą być traktowane jako kontynuacja drogi rozwoju człowieka wskazanej przez Platona. Jan Paweł II postrzega dzieła literackie jako swoiste drogowskazy i w swym aksjologicznym przesłaniu nawiązuje zarówno do wielkiej literatury światowej, jak i do mniej znanej, reprezentatywnej jedynie dla odwiedzanych narodowych. W ten sposób Papież prowadzi dialog z przedstawicielami różnych kultur i narodów. Szczególnie ceni te utwory, które ze względu na swe humanistyczne przesłanie mogą być traktowane jak ,przedpola Ewangelii”, a także te, których artystyczne piękno wprost odsłania tajemnice wiary, nadziei i miłości.

\section{WYKAZ SKRÓTÓW}

DZ Jan Paweł II. Dzieła zebrane, t. I-XVI, Wydawnictwo M, 2008.

KKK Katechizm Kościoła Katolickiego. Pallottinum, 1994.

LDK Leksykon duchowości katolickiej, red. Marek Chmielewski, Wydawnictwo M, 2002.

PDO Jan Paweł II. Pielgrzymki do Ojczyzny. Przemówienia i homilie 1979, 1983, 1987, 1991, 1995, 1997, 1999, 2002. „Znak”, 2006.

\section{BIBLIOGRAFIA I NETOGRAFIA}

\section{PODMIOTOWA}

Jan Paweł II. „Przemówienie podczas spotkania z przedstawicielami organizacji międzynarodowych. Prawdziwe kryteria postępu (12 IX 1983, Wiedeń, Austria)". DZ XI 215-217.

Jan Paweł II. „Homilia podczas mszy dla artystów. Religijny wymiar sztuki (20 V 1985 Bruksela, Belgia)”. DZ X 877-882.

Jan Paweł II. „Przemówienie pożegnalne na lądowisku przed klasztorem Sióstr od Przenajświętszej Krwi Chrystusa. Zwróćmy się do Boga, źródła wszelkiego dobra (8 IX 1985, Lichtenstein)”. DZ XI 371-371.

Jan Paweł II. „Trzeba by głos Indii sprzymierzyt się z głosem Kościoła. Homilia podczas Mszy św. dla rodzin w parku Shivaji (9 II 1986 Bombaj, Indie)”. DZ XIII 62-65.

Jan Paweł II. „Przemówienie do młodzieży zgromadzonej na stadionie Gerland. W odpowiedzi na pytania dotyczące wiary, Kościoła, świata (5 X 1986, Lyon, Francja)”. DZ X 171-182.

Jan Paweł II. „Przemówienie podczas spotkania z przedstawicielami świata nauki i sztuki. Ażeby ziemia nie zamieniła się w pustynię (26 VI 1988, Salzburg, Austria)”. DZ XI 261-264.

Jan Paweł II. „Przemówienie podczas spotkania ekumenicznego w parku Thingvellir. Jedność chrześcijan stanie się darem Boga w czasie Jego taski, (3 VI 1989, Reykjavik, Islandia)”. DZ XI 553-556.

Jan Paweł II. „Homilia wygłoszona w czasie Mszy św. (6 VI 1991 Olsztyn, Polska)”. PDO 665-673.

Jan Paweł II. „Homilia podczas Mszy św. na zakończenie Kongresu Eucharystycznego. Eucharystia i ewangelizacja (13 X 1991, Natal, Brazylia)”. DZ XII 447-449.

Jan Paweł II. „Wiara, nadzieja i miłość w perspektywie ekumenicznej. Katecheza podczas audiencji generalnej (22 XI 2000 Watykan)", www.opoka.org.pl/biblioteka/W/WP/jan_pawel_ii/audiencje/ ag_22112000.html. Dostęp 20.04.2020. 
Jan Paweł II. „Wiara w Boga pozwala odkrywać prawde, dobro i piękno. Przemówienie do przedstawicieli wspólnot religijnych oraz świata polityki, kultury i sztuki (22 V 2002, Baku, Azerbejdżan)”. DZ XIII 281-243.

\section{PRZEDMIOTOWA}

Augustyn. Wyznania. Tłum. Zygmunt Kubiak, Instytut Wydawniczy PAX, 1987.

Chlebowski, Piotr. „Rzecz o wolności stowa jako problem genologiczny”. Studia Norwidiana, t. 11, 1998, ss. 53-75.

Czuj, Jan. „Wstęp”. Augustyn. Wyznania. Tłum. Jan Czuj, De Agostini-Altaya, 2001.

Dostojewski, Fiodor. Idiota. Powieść w czterech częściach, [Dzieła Fiodora Dostojewskiego, t. VII cz. 3 rozdz. V]. Przeł. Jerzy Jędrzejewicz, przejrzał i popr. Zbigniew Podgórzec, Państwowy Instytut Wydawniczy, 1987.

Gąsiorowski, Maciej L. „«Mistrzowie podejrzeń» według Ricoeura”. Edukacja Filozoficzna. Rekonstrukcje. Interpretacje. Przeglady, vol. 57, 2014, www.edukacja-filozoficzna.uw.edu.pl/index_pliki/ ef57/08-gasiorowski.pdf. Dostęp 15.04.2020.

Góralczyk, Paweł. „Cnoty”. LDK, ss. 142-145.

Kaucha, Krzysztof. „Argument kaloniczny na wiarygodność chrześcijaństwa”. Ethos, nr 1-2 (73-74), 2006, ss. 135-147.

Kheriaty, Aaron, i John Cihak. Katolicki przewodnik po depresji. Tłum. Jakub Kołacz, Wydawnictwo M, 2013.

Kiełbasa, Jan. „Pierwsze i najpowszechniejsze: jedność, prawda, dobro i inne transcendentalia w metafizyce św. Tomasza z Akwinu”. Przegląd Tomistyczny, t. XIX, 2013, ss. 251-280.

Krawczyk, Zofia. „Rabindranath Tagore - poszukiwanie prawdy i piękna w teorii i w Szkole Poety”. Kwartalnik Pedagogiczny, nr 4(246), 2017, www.wuw.pl/data/include/cms/Kwartalnik_Pedagogiczny_4_2017.pdf\#page=96. Dostęp 22.04.2020.

Maryniarczyk, Andrzej. „Prawda”, www.ptta.pl/pef/pdf/p/prawda.pdf. Dostęp 11.03.2020.

„,Modlitwa franciszkańska”, [podaję za stroną:] www.panewniki.pl/duchowosc,modlitwy_franciszkanskie,48.html. Dostęp 22.04.2020.

Modlitwy o pokój, oprac. Stanisław Przepierski OP, Wydawnictwo 3DOM, 2014.

Moskwa, Jacek. Droga Karola Wojtyły, t. 2: Zwiastun wyzwolenia, Świat Książki, 2010.

Nawrocki, Witold. „Literatura islandzka”. Dzieje literatur europejskich, t. 2, red. Władysław Floryan, Państwowe Wydawnictwo Naukowe, 1983.

Niezgoda, Cecylian. Śladami Franciszka. Wybór pism. Przygotowanie i wstęp o. Zdzisław Kijas, Bratni Zew, 1995.

Norwid, Cyprian. Promethidion. Rzecz o dwóch dialogach z epilogiem. Wstęp i oprac. Stefan Sawicki, Universitas, 1997.

Norwid, Cyprian. „Rzecz o wolności słowa”, cz. I, wspolnotapolska.org.pl/kultura/literatura/norwid/ rzecz-o-wolnosci-slowa.pdf. Dostęp 13.03.2020.

Obrzędy sakramentu matżeństwa dostosowane do diecezji polskich. Księgarnia św. Jacka, 2019.

Paprocki, Henryk. „Dostojewski pisarzem rozpaczy czy pisarzem nadziei?”, www.liturgia.cerkiew.pl/ texty.php?id_n=104\&id=113. Dostęp 25.03.2020.

Peguy, Charles. Przedsionek tajemnicy drugiej cnoty. Przeł. Leon Zaręba, Wydawnictwo Karmelitów Bosych, 2007, issuu.com/wkb-krakow/docs/peguy_wklad_240s. Dostęp 19.04.2020.

Pereira, Katarzyna Rodrigo. „Stare i nowe: Charles Peguy - człowiek niemożliwej syntezy”. Collectanea Theologica, 69/2, 1999, ss. 71-88, bazhum.muzhp.pl/media//files/Collectanea_Theologica/ Collectanea_Theologica-r1999-t69-n2/Collectanea_Theologica-r1999-t69-n2-s71-88/Collectanea_Theologica-r1999-t69-n2-s71-88.pdf. Dostęp 15.04.2020. 
Pereira, Katarzyna Rodrigo. „Szema Karola Péguy. Człowiek pogranicza”. Roczniki Humanistyczne, t. 48, z. 5, 2000, ss. 5-24, www.ojs.tnkul.pl/index.php/rh/article/view/4429/4431. Dostęp 15.04.2020.

Sawicki, Stefan. „Wstęp”. C. Norwid. Promethidion. Rzecz o dwóch dialogach z epilogiem. Wstęp i oprac. Stefan Sawicki, Universitas, 1997.

Seul, Anastazja. „Odwołania Jana Pawła II do literatury pięknej podczas pielgrzymek do krajów anglojęzycznych". Stowo kaznodziejskie i literackie, red. Jerzy Sikora, Wydawnictwo Naukowe UKSW, 2018.

Seul, Anastazja. „Prawda. Dobro. Piękno. W kręgu literackich i nieliterackich wartości zapisanych w wypowiedziach Jana Pawła II wygłoszonych we Wrocławiu (21 czerwca 1983; 31 maja 1 czerwca 1997". Wrocławski Przeglad Teologiczny, 27, nr 1, 2019, ss. 97-122.

Seul, Anastazja. Literatura polska w wypowiedziach Jana Pawła II. Sacrum. Prawda. Dobro. Piękno. Wydawnictwo Rys, 2014.

Siemieniewski, Andrzej. „Rzeczywistości ziemskie, doczesne”, Teologia duchowości, 20.12.2008, teologia-duchowosci.blogspot.com/2008/12/ks-andrzej-siemieniewski-rzeczywistoci.html. Dostęp 29.03.2020.

Słomka, Walerian. „Miłość”. LDK, ss. 534-526.

Słomka, Walerian. „Nadzieja”. LDK, ss. 561-562.

Słomka, Walerian. „Prawda”. LDK, ss. 700-701.

Słomka, Walerian. „Wiara”. LDK, ss. 913-914.

Sołowiow, Włodzimierz. „Trzy mowy ku czci Dostojewskiego”. Okrutny talent. Dostojewski we wspomnieniach, krytyce i dokumentach. Wybór, oprac., wstęp i przypisy Zbigniew Podgórzec, Wydawnictwo Literackie, 1984.

Sosnowski, Mirosław. Bogom śpiewać i ludziom. Jan Kasprowicz-Rabindranath Tagore. Bliskie i dalekie zwiazki. Wydawnictwo Adam Marszałek, 2020.

Stopyra, Artur. Literatura i kultura Księstwa Liechtenstein. Rozprawa doktorska napisana pod kierunkiem prof. dra hab. Tomasza G. Pszczółkowskiego; Uniwersytet Warszawski, Wydział Neofilologii, Instytut Germanistyki, Warszawa, 2006.

Szczerba, Dorota. Praktyczny leksykon modlitwy. Wydawnictwo M, 2008.

Szutta, Natasza. „Książę Myszkin - «idiota» czy moralny święty?”. Filozofuj!, nr 5 (17), 2016, ss. 35-36.

Św. Franciszek. „Cnoty, które usuwają wady”. Św. Franciszek, św. Klara. Pisma. Tłum. wprowadzeń i indeksów Martyna Kulikowska, red. Wacław Michalczyk, Stanisław Styś, Wydawnictwo M, 2004

Tagore, Rabindranath. „Zbłąkane ptaki”. Myśli. Przekład i wybór K.[azimierza] Paszkowskiego, Warszawa 1923 [Drukarnia Akademicka].

Tatarkiewicz, Władysław. Dzieje sześciu pojęć. Państwowe Wydawnictwa Naukowe, 1988.

Tuczyńska, Joanna. „Rabindranath Tagore jako architekt kulturowego pomostu między Indiami i Chinami”. Gdańskie Studia Azji Wschodniej, nr 5, 2014 ss.121-136, ejournals.eu/sj/index.php/GSAW/ article/viewFile/5102/5012. Dostęp 22.04.2020.

Urbański, Stanisław. „Pokora”. LDK, ss. 647-648.

\section{OD WARTOŚCI HUMANISTYCZNYCH DO TEOLOGICZNYCH \\ O ODWOŁANIACH DO LITERATURY PIĘKNEJ W HOMILIACH I PRZEMÓWIENIACH JANA PAWŁA II}

Streszczenie

Autorka artykułu przedstawia dwa rodzaje wartości, jakie są obecne w tych wypowiedziach Papieża, w których przywołuje on literaturę piękną. Są to najpierw wartości humanistyczne zakorzenione 
w filozofii bytu: prawda, dobro, piękno, o których piszą mniej i bardziej znani twórcy różnych narodów. Wartości te otwarte na wymiar transcendentny otwierają horyzont teologiczny. Niektóre odwołania do literatury odsłaniają trzy cnoty teologalne, które reprezentują chrześcijańską aksjologię. Dzieła literackie stanowią dla Papieża locus theologicus. W jego wypowiedziach znajduje się miejsce dla autorów reprezentujących narody, które odwiedza (np. Rabindrmath Tagore w Indiach, Jon Svensson w Islandii), a także dla twórców, których dzieła należą do bogactwa kultury światowej i były cytowane poza ich krajem (np. Fiodor Dostojewski w Austrii, św. Augustyn we Francji i Brazylii). Papież, odwołując się do tych dwóch rodzajów literatury, nawiązuje kontakt z kulturą narodów, które odwiedzał, oraz przybliża im kulturę światową. Przekonuje o możliwym spotkaniu wartości humanistycznych i teologicznych.

Słowa kluczowe: Jan Paweł II; literatura piękna; prawda; dobro; piękno; cnoty teologalne

\section{FROM HUMANISTIC TO THEOLOGICAL VALUES \\ ON LITERARY REFERENCES \\ IN THE HOMILIES AND PRONOUNCEMENTS OF JOHN PAUL II}

\section{Sum mary}

The author of this article shows two types of values that are present in those pronouncements when the Pope recalls examples from belles-lettres. First and foremost, he speaks of the humanistic values rooted in the philosophy of the essence, namely the truth, goodness and beauty that are widely found in works of both less and more well-known authors of different nations. The aforementioned values, having a transcendent backdrop, open up the theological world. Some of those references unveil the three theological virtues which actually represent Christian axiology. For the Pope, the belles-lettres works become locus theologicus. In his pronouncements, the Pope not only mentions various authors from the particular nations he visited (e.g. Rabindranath Tagore from India, Jon Svensson from Island), but also those authors whose works now belong to the whole world (such as Fyodor Dostoyevsky, mentioned in Australia, or St. Augustine in France and Brazil). Recalling those authors and their works, the Pope connected with those nations he visited, and created a special place in order to bring to those nations the greatest works of world literature. He was adamant that humanistic and theological values can be placed equally next to each other.

Keywords: John Paul II; belles-lettres; truth; goodness; beauty; theological virtues 